\title{
Efficiency of using SNP markers in the MSTN gene in the selection of the Pushkin breed chickens
}

\author{
N.V. Dementeva, A.B. Vakhrameev, T.A. Larkina, O.V. Mitrofanova $\otimes$ \\ Russian Research Institute of Farm Animal Genetics and Breeding - Branch of the L.K. Ernst Federal Science Center for Animal Husbandry, \\ Pushkin, St. Petersburg, Russia \\ 凶e-mail:mo1969@mail.ru
}

In the poultry industry, indicators reflecting the growth rate of young stock and the exterior characteristics of chickens are important benchmarks for breeding. Traditional selection based on phenotypic evaluation is characterized by low efficiency with a low character inheritance ratio and is difficult to apply in small groups of animals and birds bred in bioresource collections. The use of molecular genetic markers associated with economically important traits makes it possible to carry out early selection of birds. This entails an increase in the profitability of the poultry industry. Recently, single nucleotide polymorphisms (SNPs) have served as convenient markers for selection purposes. For five generations (P1-P5), an experimental selection of hens of the Pushkin breed was carried out for live weight. It was based on selection for single nucleotide polymorphism rs 313744840 in the MSTN gene. As a result, a significant increase in the frequency of allele $\mathrm{A}$ in this gene, from 0.11 to 0.50 , took place. The association of SNP markers with meat qualities in the experimental group led to changes in the exterior profile of an adult bird at 330 days of age. The individuals with the AA and AG genotypes had the greatest live weight and longest body. As a result of selection, the bird on average became larger due to an increase in the number of heterozygous individuals with long bodies and large chest girths. The depth of the chest and the width of the pelvis increased due to an increase in the frequency of allele $A$ in the experimental population. A tendency towards an increase in these indicators with the substitution of $G$ with $A$ in the genotype was found. Saturation of the population with desirable alleles led to an increase in the average live weight of the chickens. Analysis of the exterior parameters of adult birds showed that this growth is achieved by increasing the depth and volume of the bird body, and not by increasing the length of the limbs. Thus, marker selection carried out for five generations in the experimental population of Pushkin breed chickens to increase body weight has reliably $(p<0.001)$ changed the exterior profile of adult birds.

Key words: PCR-RFLP; polymorphism; myostatin; chickens; marker selection; exterior.

For citation: Dementeva N.V., Vakhrameev A.B., Larkina T.A., Mitrofanova O.V. Efficiency of using SNP markers in the MSTN gene in the selection of the Pushkin breed chickens. Vavilovskii Zhurnal Genetiki i Selektsii=Vavilov Journal of Genetics and Breeding. 2019;23(8):993-998. DOI 10.18699/VJ19.575

\section{Эффективность использования SNP-маркеров в гене $M S T N$ в селекции кур пушкинской породы}

\author{
Н.В. Аементьева, А.Б. Вахрамеев, Т.А. Ааркина, О.В. Митрофанова ® \\ Всероссийский научно-исследовательский институт генетики и разведения сельскохозяйственных животных - \\ филиал Федерального научного центра животноводства - ВИЖ им. академика Л.К. Эрнста, Пушкин, Санкт-Петербург, Россия \\ 凶e-mail: mo1969@mail.ru
}

В птицеводстве показатели, отражающие интенсивность роста молодняка и экстерьерные характеристики кур, - важные ориентиры для селекции. Традиционный селекционный отбор, основанный на фенотипической оценке, отличается невысокой эффективностью при низком коэффициенте наследуемости признака, и в малочисленных группах животных и птиц, разводимых в биоресурсных коллекциях, его сложно применять. Использование молекулярно-генетических маркеров, связанных с экономически значимыми признаками, позволяет проводить ранний отбор птицы. Это влечет за собой повышение рентабельности птицеводства. В последнее время удобными для селекционных целей маркерами служат однонуклеотидные полиморфизмы (SNP). В опытной популяции кур пушкинской породы в течение пяти поколений (P1-P5) проводили маркерную селекцию на увеличение живой массы. В ее основе был отбор по однонуклеотидной замене rs313744840 в гене MSTN. В результате отбора за этот период произошло значительное увеличение частоты аллеля А в этом гене: с 0.11 до 0.50. Ассоциация SNP-маркера с мясными качествами в опытной группе кур привела к изменениям экстерьерного профиля взрослой птицы в возрасте 330 дней. Наибольшей живой массой и длинным корпусом отличались особи с генотипами AG и AA. B результате селекции птица в среднем стала крупнее за счет увеличения количества гетерозиготных особей с длинным корпусом и большим обхватом груди. Глубина груди и ширина таза увеличились параллельно с ростом частоты аллеля А в опытной популяции. Обнаружена тенденция к увеличению этих показателей при за- 


\begin{abstract}
мене G на А в генотипе. Насыщение популяции желательными аллелями привело к росту средних показателей живой массы кур. Анализ экстерьерных параметров взрослой птицы показал, что этот рост достигается за счет увеличения глубины и объема корпуса птицы, а не роста длины конечностей. Таким образом, в опытной популяции кур пушкинской породы на протяжении пяти поколений проведена маркерная селекция на увеличение живой массы, которая достоверно ( $p<0.001)$ изменила экстерьерный профиль взрослой птицы.
\end{abstract}

Ключевые слова: ПЦР-ПДРФ; полиморфизм; миостатин; куры; маркерная селекция; экстерьер.

\section{Introduction}

In the poultry industry, indicators reflecting the growth rate of young stock and the conformation characteristics of chickens are important breeding benchmarks. The use of molecular genetic markers associated with economically important traits allows for the early selection of birds, which entails an increase in the profitability of the poultry industry. Recently, single nucleotide polymorphisms (SNPs) have served as convenient markers for this purpose. Chicken genomes include 13.93 millions such polymorphisms (Boschiero et al., 2018). Since the identification of SNP is not difficult and the search focuses only on genetic sequences of interest, this reduces the time and cost of evaluation (Smaragdov, 2009).

Currently, there are many studies in the world aimed at identifying genomic associations between individual SNPs and breeding traits in chickens (Fornari et al., 2014; Cruz et al., 2015; Grupioni et al., 2017). This abundance of identified links in the future can help in the mapping of polymorphisms deterrmining complex traits in poultry. Modern technologies based on work with SNP chips make it possible to identify genome-wide associations for growth rates in chickens (Zhang et al., 2015). But selection by individual markers continues to be a convenient tool for achieving genetic progress in populations of farm animals and birds. It is especially relevant when breeding small and gene pool populations of chickens.

Traditional selection is based on a phenotypic evaluation, characterized by low efficiency and complexity. It is not always possible to use it for quantitative traits, as well as for small groups of animals and birds, which are usually the populations bred in bioresource collection farms. In this case, it is reasonable to use marker-based selection methods, the so-called MAS (marker-assisted selection) (Khlestkina, 2014). This way allows breeders to choose farm animals with high rates of breed specific traits and reproduction early and efficiently. This is a selection process that focuses on the trait of interest based on genetic markers associated with it and leads to the accumulation of individuals in the population with the desired combinations of genes (Collard et al., 2005).

When using this method on birds with a small population size, it is necessary to control genetic diversity. Similar studies were carried out on indigenous chicken breeds ( $\mathrm{Li}$ et al., 2008; Guo et al., 2016). Until now, genetic studies of the conformation traits of the birds have been focused on the qualitative indicators of the appearance of the birds, such as color and shape (Sun et al., 2015; Guo et al., 2016). At the same time, live weight and conformation traits are important goals of breeding in the poultry industry. Consequently, one should not overlook the search for links between genomic loci responsible for the growth and accumulation of muscle mass.
One of these genes that directly affects the body weight of various animals and humans which has been under investigation for the past twenty years is myostatin gene MSTN (Zhang et al., 2012). Myostatin, a protein that inhibits the growth and differentiation of muscle tissue in the body, acts as a negative regulator of skeletal muscle mass. This protein is secreted by muscle cells and acts on the basis of feedback regulation. With increasing muscle mass increases the secretion of myostatin, which inhibits further muscle growth.

Natural mutations that lead to a decrease in the amount of myostatin and/or suppress its function were identified in various species of animals and birds, including chickens. In latter a large number of SNPs have been found in this gene and their effect on growth rate, reproductive parameters and meat quality have been documented (Baron et al., 2002; Dementeva et al., 2017). In addition, mutations in non-coding regulatory regions were identified in various breeds of sheep, pig, dog, and chicken, which affect the expression level of $M S T N$, and, consequently, growth and muscle mass (Hu et al., 2013). The effect of SNP in this gene on live weight under various growing conditions and mortality of chickens was studied (Ye et al., 2007).

The aim of our study was to determine the effect of the conducted MAS by rs313744840 SNP in the myostatin gene on the conformation traits of Pushkin chicken breed from the Russian Research Institute of Farm Animal Genetics and Breeding bioresource collection farm.

The specific tasks of the research included tracing the dynamics of the rs 313744840 allele frequency in the myostatin gene in the population of Pushkin chicken breed over a number of years, and also analyzing the associations of rs 313744840 replacement in the myostatin gene with the conformation traits of poultry.

\section{Materials and methods}

The material for the study was DNA isolated from the blood of hens and cocks of the experimental population of Pushkin's breed, which was selected during five generations (P1-P5) for rs313744840 replacement in the MSTN gene and live weight. This population was formed on the basis of the Russian Research Institute of Farm Animal Genetics and Breeding bioresource collection farm "Genetic collection of rare and endangered breeds of chickens" (Pushkin, St. Petersburg).

At birth, chickens were individually tagged. During raizing, they were regularly weighed in 7, 33, 80 and 90 days. At the same time there was a culling of sick or injured chickens. Birds with the desired genotype for replacement in the myostatin gene was selected in the breeding core, whose representatives at the age of 330 days were weighed and evaluated by 
conformation traits. In addition, in the P2-P4 generations the selection of chickens by weight was not carried out. In the P5 generation, a strict culling of chickens was carried out and birds with an increased growth rate, high body weight and good egg production of mothers was taken to the breeding core, even if their genotype for rs313744840 replacement in the MSTN gene was different from the desired one. The following traits were measured: body length, chest girth, tarsus girth, keel length, tarsus length, hip length, chest depth, pelvis width, chest width in the clavicle, chest angle. As a control, a population of chickens of Pushkin breed from the same bioresource collection farm was taken, which was contained under similar conditions in group breeding.

Blood for DNA extraction was collected at the age of 33 days from a wing vein into a microtube containing $50 \mu \mathrm{l}$ of 0.5 mM EDTA Ph 8.0 as an anticoagulant. Samples were stored at $-20^{\circ} \mathrm{C}$ until use. Genomic DNA was isolated by a standard phenol-detergent method.

Detection of a single nucleotide polymorphism was performed using the PCR-RFLP method. Tools for the detection of SNP are presented in Table 1. Polymerase chain reaction was performed according to the previously described procedure (Mitrofanova et al., 2017).

For electrophoresis, $1.5 \%$ agarose gels containing ethidium bromide fluorescent dye and TBE buffer (45 mM Tris-borate, $1 \mathrm{mM}$ EDTA) were used. The mixture after restriction reaction was introduced into wells of the gel. Electrophoresis was carried out for $1 \mathrm{~h}$ at an operating voltage of $150 \mathrm{~V}$. The fluorescence signal was photographed in the gel documentation system (Kodak).

Based on the genotyping, one-factor analysis of variance was performed to identify differences in productive characteristics in the SigmaPlot software package (version 12.0.5) based on the Shapiro-Wilk criteria and the Student's $t$-test.

Analysis of differences in conformation traits in chicken genotypic groups was carried out using the analysis of vari- ance analysis for multiple comparisons (All Pairwise Multiple Comparison Procedures).

\section{Results}

For five generations (2012-2016) in the experimental population of Pushkin's chicken breed, selection was made to increase the frequency of the allele A by replacement in rs313744840 locus in MSTN gene. As a result of the selection over this period, there was a significant increase in the frequency of allele A from 0.11 to 0.50 (Table 2).

Since the critical $\chi^{2}$ is 3.84 , violation in Hardy-Weinberg equilibrium was observed in the P3 generation due to an excess of GG homozygotes, and in the P5 generation - due to an excess of heterozygotes.

As part of the study of the association of SNP marker with meat qualities in the experimental group, a comformation evaluation of adult birds aged 330 days was carried out. According to the results in the P5 generation evaluation, the selection carried out reliably increased $(p<0.001)$ the length of the body, the girth and depth of the breast, the length of the keel, the width of the breast, the length of the tarsus and the width of the pelvis in chickens of the experimental population compared to the control group (Table 3 ). The chest angle in P5 chickens increased in comparison with the chickens of the previous $\mathrm{P} 4$ generation, but did not differ from the chest angle of chickens of the control population.

Table 4 presents the analysis of differences between genotypes in chickens in the P5 generation of the experimental population by replacement in rs313744840 locus in MSTN gene. The heterozygotes of AG differed from other individuals in body weight and on average weighed $2731 \pm 59 \mathrm{~g}$. They showed a significant increase in body size by three traits (body length, taped body length, diagonal body length). By the traits of the chest depth, the chest width at clavicle, the pelvis width, there is a tendency to trait increase when replacing $\mathrm{G}$ with $\mathrm{A}$ in the genotype.

Table 1. Single nucleotide polymorphism detection tools

\begin{tabular}{|c|c|c|c|c|c|}
\hline SNP & Replacement & $\begin{array}{l}\text { Annealing tem- } \\
\text { perature, }{ }^{\circ} \mathrm{C}\end{array}$ & Primers $\left(3^{\prime}-5^{\prime}\right)$ & Endonuclease & $\begin{array}{l}\text { Fragment size, } \\
\text { bp }\end{array}$ \\
\hline rs313744840 & $A / G$ & 60 & $\begin{array}{l}\text { aaccaatcgtcggttttgac } \\
\text { cgttctctgtgggctgacta }\end{array}$ & Mspl & $297,260,37$ \\
\hline
\end{tabular}

Table 2. Dynamics of changes in the frequencies of genotypes and alleles for the replacement in rs313744840 locus in MSTN gene in the course of directed selection in chickens of the Pushkin breed of the bioresource collection farm

\begin{tabular}{|c|c|c|c|c|c|c|c|}
\hline \multirow{2}{*}{$\begin{array}{l}\text { Chicken } \\
\text { generation }\end{array}$} & \multirow[t]{2}{*}{ Indicator } & \multicolumn{3}{|c|}{ Genotypes } & \multicolumn{2}{|l|}{ Allele } & \multirow[t]{2}{*}{$\chi^{2}$} \\
\hline & & AA & $A G$ & GG & A & G & \\
\hline \multirow[t]{2}{*}{$P 2,2013$} & Livestock & 4 & 22 & 113 & & & \\
\hline & Frequency & 0.03 & 0.16 & 0.81 & 0.11 & 0.89 & 2.41 \\
\hline \multirow[t]{2}{*}{ P3, 2014} & Livestock & 32 & 71 & 143 & & & \\
\hline & Frequency & 0.13 & 0.29 & 0.58 & 0.28 & 0.72 & 18.87 \\
\hline \multirow[t]{2}{*}{ P4, 2015} & Livestock & 64 & 135 & 69 & & & \\
\hline & Frequency & 0.24 & 0.50 & 0.26 & 0.49 & 0.51 & 0.02 \\
\hline \multirow[t]{2}{*}{ P5, 2016} & Livestock & 87 & 243 & 90 & & & \\
\hline & Frequency & 0.21 & 0.58 & 0.21 & 0.5 & 0.5 & 10.34 \\
\hline
\end{tabular}


Table 3. Conformation evaluation of the experimental population of Pushkin chickens (populations P4 and P5) in comparison with the control population

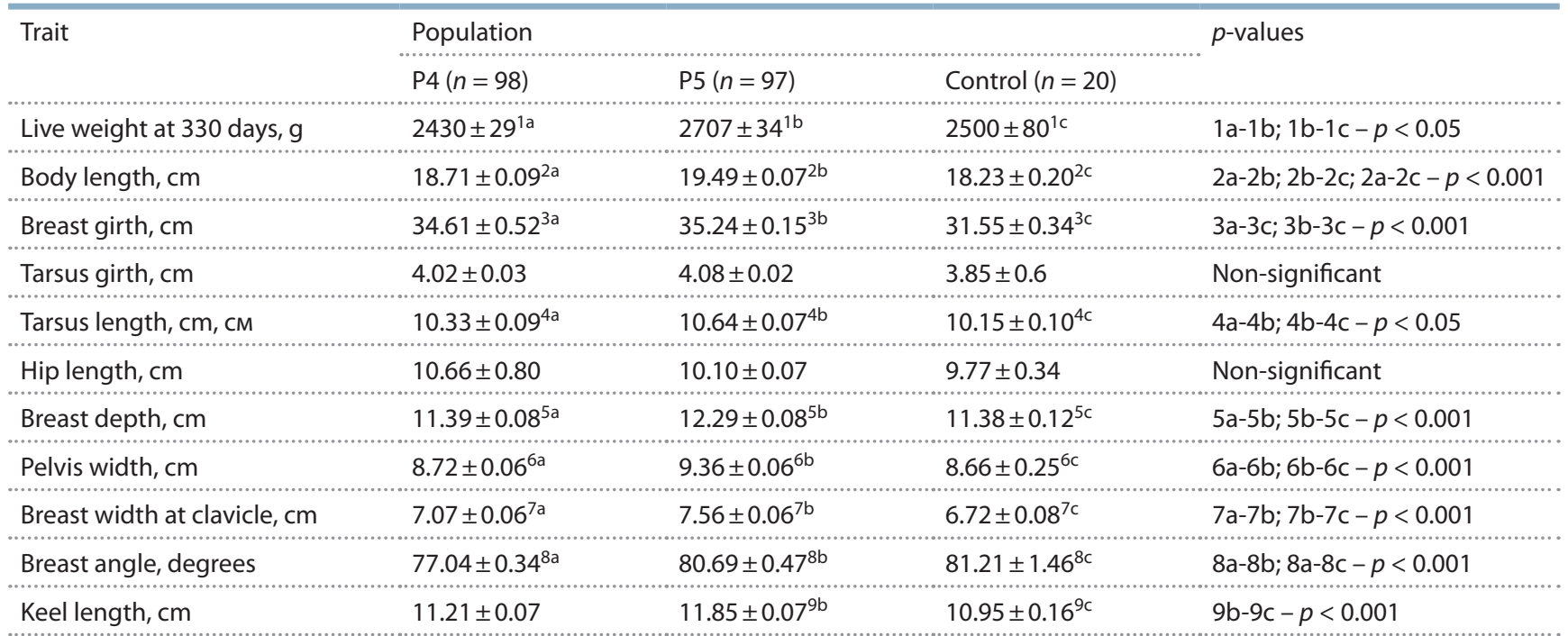

Table 4. Conformation evaluation of the experimental population of P5 chickens of various genotypes by rs313744840 replacement in MSTN gene

\begin{tabular}{|c|c|c|c|c|}
\hline \multirow[t]{2}{*}{ Trait } & \multicolumn{3}{|l|}{ Genotype } & \multirow[t]{2}{*}{$p$-values } \\
\hline & $\mathrm{AA}(n=34)$ & $\mathrm{AG}(n=48)$ & $\mathrm{GG}(n=9)$ & \\
\hline Live weight at 330 days, $g$ & $2599 \pm 44^{1 a}$ & $2731 \pm 59^{1 b}$ & $2436 \pm 117^{1 c}$ & $1 a-1 b ; 1 b-1 c-p<0.05$ \\
\hline Body length, $\mathrm{cm}$ & $19.10 \pm 0.11^{2 a}$ & $19.58 \pm 0.10^{2 b}$ & $19.12 \pm 0.16^{2 c}$ & $2 a-2 b ; 2 b-2 c-p<0.05$ \\
\hline Taped body length, cm & $21.65 \pm 0.13^{3 a}$ & $22.34 \pm 0.14^{3 b}$ & $21.56 \pm 0.28^{3 c}$ & $3 a-3 b ; 3 b-3 c-p<0.05$ \\
\hline Breast girth, cm & $34.71 \pm 0.22$ & $35.25 \pm 0.26$ & $34.28 \pm 0.45$ & Non-significant \\
\hline Breast width at clavicle, $\mathrm{cm}$ & $7.53 \pm 0.09$ & $7.43 \pm 0.08$ & $7.01 \pm 0.26$ & Non-significant \\
\hline Breast depth, cm & $12.42 \pm 0.17$ & $12.10 \pm 0.12$ & $12.03 \pm 0.20$ & Non-significant \\
\hline Tarsus girth, cm & $3.97 \pm 0.04$ & $4.02 \pm 0.02$ & $3.97 \pm 0.6$ & Non-significant \\
\hline Keel length, cm & $11.66 \pm 0.09$ & $11.72 \pm 0.11$ & $11.83 \pm 0.25$ & Non-significant \\
\hline Tarsus length, cm & $10.68 \pm 0.11$ & $10.56 \pm 0.11$ & $10.53 \pm 0.31$ & Non-significant \\
\hline Hip length, cm & $9.97 \pm 0.13$ & $10.06 \pm 0.10$ & $9.83 \pm 0.19$ & Non-significant \\
\hline Shin length, $\mathrm{cm}$ & $14.38 \pm 0.12$ & $14.68 \pm 0.10$ & $14.67 \pm 0.19$ & Non-significant \\
\hline Shin girth, $\mathrm{cm}$ & $11.89 \pm 0.20$ & $12.03 \pm 0.13$ & $11.61 \pm 0.33$ & Non-significant \\
\hline Pelvis width, $\mathrm{cm}$ & $9.34 \pm 0.10$ & $9.25 \pm 0.10$ & $9.09 \pm 0.18$ & Non-significant \\
\hline Breast angle, degrees & $81.06 \pm 0.67$ & $80.62 \pm 0.69$ & $79.33 \pm 1.9$ & Non-significant \\
\hline
\end{tabular}

\section{Discussion}

The myostatin gene in chickens in our work was selected for use as a selection criterion. Interest for its investigation does not fade. Various allelic variants has been identified, the relationships of single nucleotide substitutions in this gene with productive traits in various animals has been determined (Ye et al., 2007; He et al., 2013; Hope et al., 2013; Tu et al., 2013; Dementeva et al., 2017; Mitrofanova et al., 2017; Rooney et al., 2017). There are studies confirming the associative links of SNPs in the region of the myostatin gene with the growth rate of young chickens and body weight (Dushyanth et al., 2016).
Study of the results of chicken breeding by the marker allele of the myostatin gene in non-industrial breeds yet was not conducted. At the beginning of our work, several SNPs in the myostatin gene (Dementeva et al., 2018; Mitrofanova, Dementeva, 2018) were under study, but only the replacement in the rs313744840 position of this gene was effective for selection for live weight in birds. The marker-assisted selection in the Pushkin gene pool breed has been carried out for 5 years. As a result, an increase in live weight of the experimental chicken population along with a shift in the frequency of occurrence of allele A from 0.11 to 0.50 was achieved. 
The violation in Hardy-Weinberg equilibrium is observed in the P3 generation due to the disproportionate selection of AA homozygotes compared with the $\mathrm{P} 2$ generation, and in the P5 generation due to an excess of heterozygotes taken into the breeding core by their productivity criterion. In the course of breeding, the main selection criterion for hens was not only the genotype of the individual, but also the reproductive qualities of mothers (egg production, egg mass). Perhaps the increase in the pelvis width (see Table 3 ) was a consequence of the selection for egg mass increase.

The association of the SNP marker with meat qualities in the experimental group led to changes in the conformation profile of an adult bird at 330 days of age. An analysis of differences in conformation traits between genotypes showed that individuals with a heterozygous and AA genotypes were characterized by the greatest live weight and body length. For these genotypes, there was a significant increase in the size of the body by three traits: body length, taped body length, diagonal body length. As a result of breeding, birds on average became larger due to an increase in the number of heterozygous individuals in a population with a long body and a large chest girth. The chest depth and the pelvis width increased due to an increase in the frequency of allele $\mathrm{A}$ in the experimental population compared to chickens from the control group. A tendency to an increase in these traits with the replacement of $\mathrm{G}$ by $\mathrm{A}$ in the genotype was found. Since the selection was carried out over several years, one can witness the saturation of the population with the desired alleles that led to an increase in the average chickens live weight. Analysis of the conformation traits of adult birds demonstrated that this increase is achieved by increasing the depth and volume of the bird body, and not by limbs elongating.

\section{Conclusion}

Thus, marker-assisted selection conducted for five generations in the experimental population of Pushkin chicken breed resulted in body weight increase. Breeding carried out on this population changed the conformation profile of adult birds at 330 days of age $(p<0.001)$. There was an increase in the body length, chest girth and depth, the keel length, the chest width, and the pelvis width.

\section{References}

Baron E.E., Wenceslau A.A., Alvares L.E., Nones K., Ruy D.C., Schmidt G., Zanella E., Coutinho L., Ledur M.C. High level of polymorphism in the Myostatin chicken gene. In: Proc. of the 7th World Congress on Genetics Applied to Livestock Production, August 19-23, 2002. Montpellier, France, 2002;19-23.

Boschiero C., Moreira G., Gheyas A., Godoy T., Gasparin G., Mariani P., Paduan M., Cesar A., Ledur M., Coutinho L. Genomewide characterization of genetic variants and putative regions under selection in meat and egg-type chicken lines. BMC Genomics. 2018;19(83):1-18. DOI 10.1186/s12864-018-4444-0.

Collard B., Jahufer M., Brouwer J., Pang E. An introduction to markers, quantitative trait loci (QTL) mapping and marker-assisted selection for crop improvement: The basic concepts. Euphytica. 2005; 142:169-196. DOI 10.1007/s10681-005-1681-5.

Cruz V., Schenkel F., Savegnago R., Grupioni N., Stafuzza N., Sargolzaei M., Ibelli A., Peixoto J., Ledur M., Munari D. Association of apolipoprotein B and adiponectin receptor 1 genes with carcass, bone integrity and performance traits in a paternal broiler line. PLoS One. 2015;10(8):e0136824. DOI 10.1371/journal.pone.0136824.
Dementeva N.V., Mitrofanova O.V., Kudinov A.A. The effect of different diets of feeding on the result of associative analysis of polymorphism in the MSTN gene and growth of live weight in chickens. Mezhdunarodnyy Zhurnal Prikladnykh i Fundamentalnykh Issledovaniy $=$ International Journal of Applied and Fundamental Research 2018;6:145-148. DOI 10.23670/IRJ.2018.72.6.017. (in Russian)

Dementeva N., Mitrofanova O., Tyshchenko V., Terletskiy V., Yakovlev A. The rate of weight gain and productivity of a chicken broiler cross with various polymorphic types of the myostatin gene. Russ. J. Genet.: Appl. Res. 2017;7(1):1-5. DOI 10.1134/S207905971701004X.

Dushyanth K., Bhattacharya T.K., Shukla R., Chatterjee R.N., Sitaramamma T., Paswan C., Guru Vishnu P. Gene expression and polymorphism of Myostatin gene and its association with growth traits in chicken. Anim. Biotechnol. 2016;27(4):269-277. DOI 10.1080/ 10495398.2016.1182541.

Fornari M., Zanella R., Ibelli A., Fernandes L., Cantao M., ThomazSoccol V., Ledur M., Peixoto J. Unraveling the associations of osteoprotegerin gene with production traits in a paternal broiler line. SpringerPlus. 2014;3(682). DOI 10.1186/2193-1801-3-682.

Grupioni N., Stafuzza N., Carvajal A., Ibelli A., Peixoto J., Ledur M., Munari D. Association of RUNX2 and TNFSF11 genes with production traits in a paternal broiler line. Genet. Mol. Res. 2017;16(1). DOI $10.4238 /$ gmr16019443.

Guo X., Fang Q., Ma C., Zhou B., Wan Y., Jiang R. Whole-genome resequencing of Xishuangbanna fighting chicken to identify signatures of selection. Genet. Sel. Evol. 2016;48(62). DOI 10.1186/s12711016-0239-4.

He Y.L., Wu Y.H., Quan F.S., Liu Y.G., Zhang Y. Comparative analysis of myostatin gene and promoter sequences of Qinchuan and Red Angus cattle. Genet. Mol. Res. 2013;12(3):3398-3406. DOI 10.4238/2013.September.4.6.

Hope M., Haynes F., Oddy H., Koohmaraie M., Al-Owaimer A., Geesink $\mathrm{G}$. The effects of the myostatin $\mathrm{g}+6723 \mathrm{G}>\mathrm{A}$ mutation on carcass and meat quality of lamb. Meat Sci. 2013;95(1):118-122. DOI 10.1016/j.meatsci.2013.03.029.

Hu W., Chen S., Zhang R., Liu Y. Single nucleotide polymorphisms in the upstream regulatory region alter the expression of myostatin. In Vitro Cell. Dev. Biol. Anim. 2013;49(6):417-423. DOI 10.1007/ s11626-013-9621-5.

Khlestkina E.K. Molecular markers in genetic studies and breeding. Russ. J. Genet.: Appl. Res. 2014;4(3):236-244. DOI 10.1134/S2079 059714030022

Li H., Zhu W., Chen K., Song W., Shu J., Han W. Associations between GHR and IGF-1 gene polymorphisms, and reproductive traits in Wenchang chickens. Turk. J. Vet. Anim. Sci. 2008;32(4): 281-285.

Mitrofanova O., Dementeva N., Krutikova A., Yurchenko O., Vakhrameev A., Terletskiy V. Association of polymorphic variants in $M S T N, P R L$, and $D R D 2$ genes with intensity of young animal growth in Pushkin breed chickens. Cytol. Genet. 2017;51(3);179-184. DOI 10.3103/S0095452717030082.

Rooney M.F., Porter R.K., Katz L.M., Hill E.W. Skeletal muscle mitochondrial bioenergetics and associations with myostatin genotypes in the Thoroughbred horse. PLOS One. 2017;12(11):e0186247. DOI 10.1371/journal.pone. 0186247 .

Smaragdov M.G. Genomic selection as a possible accelerator of traditional selection. Russ. J. Genet. 2009;45(6):633-636. DOI 10.1134/ S1022795409060015.

Sun Y., Liu R., Zhao G., Zheng M., Sun Y., Yu X., Li P., Wen J. Genome-wide linkage analysis identifies loci for physical appearance traits in chickens. G3 (Bethesda). 2015;5(10):2037-2041. DOI 10.1534/g3.115.020883.

Tu P.-A., Lo L.-L., Chen Y.-C., Hsu C.-C., Shiau J.-W., Lin E.-C., Wang P.-H. Polymorphisms in the promoter region of myostatin gene are associated with carcass traits in pigs. J. Anim. Breed. Genet. 2013;131(2):116-122. DOI 10.1111/jbg.12053.

Ye X., Brown S., Nones K., Coutinho L., Dekkers J., Lamont S. Associations of myostatin gene polymorphisms with performance and 
mortality traits in broiler chickens. Genet. Sel. Evol. 2007;39(1): 73-89. DOI 10.1051/gse:2006029.

Zhang G., Fan Q., Zhang T., Wang J., Wang W., Xue Q., Wang Y. Genome-wide association study of growth traits in the Jinghai Yellow chicken. Genet. Mol. Res. 2015;14(4):15331-15338.
Zhang G., Zhang L., Wei Y., Wang J., Ding F., Dai G., Xie K. Polymorphisms of the myostatin gene and its relationship with reproduction traits in the Bian chicken. Anim. Biotechnol. 2012;23(3):184-193. DOI 10.1080/10495398.2012.681411.

\section{ORCID ID}

N.V. Dementeva orcid.org/0000-0003-0210-9344

A.B. Vakhrameev orcid.org/0000-0001-5166-979X

T.A. Larkina orcid.org/0000-0002-7764-1338

O.V. Mitrofanova orcid.org/0000-0003-4702-2736

Acknowledgements. This study was carried out within the framework of the state task AAAA-A18-118021590138-1 using chickens from the Bioresource Collection of the CCU "Genetic collection of rare and endangered breeds of chickens" (Russian Research Institute of Farm Animal Genetics and Breeding, St. Petersburg, Pushkin). The authors are grateful to O.P. Yurchenko, creator of the Pushkin breed of chickens, for the opportunity to use this breed in our research.

Conflict of interest. The authors declare no conflict of interest.

Received November 1, 2018. Revised June 5, 2019. Accepted June 10, 2019. 